\title{
Necrobacilose interdigital em bovino com tratamento por pefusão regional: relato de caso
}

Lucas Santana da Fonseca ${ }^{[a]}$, Antonio Marcos Guimarães Ginelli[a], Matheus Castro Franco ${ }^{[a]}$, Thiago Jhonatha Fernandes Silva ${ }^{[b]}$, Waldelucy Karina Bomfim Felix da Silva ${ }^{[c]}$, Janyele Silva Leite ${ }^{[c]}$, Kaique Myke Nascimento Brito ${ }^{[c]}$, José Valmir Tenório Ferreira Júnior ${ }^{[d]}$, José Wilson Mendes Júnior ${ }^{[e]}$

\author{
[a] Médico veterinário, Hospital Veterinário Rancho Bela Vista, Serra, ES, Brasil \\ [b] Programa de Pós-Graduação em Biociência Animal, Universidade de São Paulo (USP), São Paulo, SP, Brasil \\ [c] Universidade Federal de Alagoas (UFA), Viçosa, AL, Brasil \\ ${ }^{[\mathrm{d}]}$ Médico veterinário
}

*Autor correspondente

e-mail: lucasfonseca1989@gmail.com

\section{Resumo}

Afecções podais dos bovinos apresentam grande variação clínica, resultando em perdas econômicas para os criatórios. A doença é causada por uma infecção bacteriana mista, sendo o Dichelobacter nodosus e o Fusobacterium necrophorus seus principais agentes causadores. É uma infecção necrótica aguda ou subaguda, que atinge o tecido conjuntivo subcutâneo da região interdigital e causa intensa claudicação. Os sinais normalmente são claudicação, alteração na estação de locomoção, lesão na pele interdigital, odor característico, secreção serosa, lesões ulcerativas, comprometimento dos talões, destruição do tecido córneo, sensibilidade à palpação, tecido de aspecto verrugoso. 0 diagnóstico é clínico através da anamnese, apresentação e sintomas. Correção funcional dos cascos deve ser feita de forma rotineira, restabelecendo as proporções normais dos mesmos, restaurando posição dos membros e favorecendo distribuição adequada do peso. Faz-se bandagem com aplicação tópica de adstringentes (sulfato de cobre e sulfa em pó) ou de uma pomada à base de tetraciclina em pó com spray à base de violeta genciana. Relata-se neste trabalho, o caso de uma vaca mestiça, de aptidão leiteira, com aproximadamente 6 anos, no oitavo de gestação, com sinais característicos de necrobacilose e histórico de claudicar do membro anterior direito há mais de 6 meses, com tratamento tópico e pedilúvios realizados anteriormente sem sucesso. Realizou-se bloqueio perineural com lidocaína $2 \%$ sem vasoconstritor, quatro pontos do boleto e paradígito, limpeza com gaze do exsudato da região necrótica com clorexidina degermante $2 \%$ e lavagem com solução de permanganato de potássio 2\%. Foi efetuada extirpação cirúrgica do tecido necrótico e hiperqueratinizado, verrugoso, com margem de segurança, objetivando debelar o problema. Uma bandagem compressiva com unguento e sulfato de 
cobre foi colocada, sem compressão para que a infecção não disseminasse. Após todos os procedimentos, foi realizada a tricotomia, antissepsia com clorexidina degermante $2 \%$ e clorexidina alcoólica $0,5 \%$ para perfusão regional com antibióticos na veia cefálica direita, com garrote acima do carpo para diminuir o retorno venoso, no total de $60 \mathrm{ml}$, onde um frasco de ceftiofur $1 \mathrm{G}+20$ mililitros de lidocaína $2 \%$ sem vasoconstritor e 40 mililitros de solução fisiológica $0,9 \%$ para preencher o volume. 0 garrote foi deixado por 30 minutos, contados desde a colocação até a canulação e total infusão. A troca do curativo foi realizada com 48 horas e uma nova perfusão regional, seguindo o mesmo protocolo, foi realizada com sucesso. 0 curativo foi trocado posteriormente a cada 48 horas, totalizando seis curativos até o total fechamento da ferida. Após o terceiro curativo, deixou-se de usar o sulfato de cobre e usou-se apenas o unguento e bandagem. 0 resultado foi bem satisfatório, pois a vaca voltou a caminhar e alimentar-se melhor devido à realização da cirurgia de extirpação e perfusão regional. Podemos considerar que a necrobacilose interdigital é uma podopatia frequente e que a extirpação cirúrgica associada à perfusão regional foi o diferencial para maximizar a recuperação. 